\title{
Factors affecting oxidative peat decomposition due to land use in tropical peat swamp forests in Indonesia
}

\section{$\operatorname{AUTHOR}(\mathrm{S})$ :}

Itoh, Masayuki; Okimoto, Yosuke; Hirano, Takashi; Kusin, Kitso

\section{CITATION:}

Itoh, Masayuki ...[et al]. Factors affecting oxidative peat decomposition due to land use in tropical peat swamp forests in Indonesia. Science of The Total Environment 2017, 609: 906-915

\section{ISSUE DATE:}

2017-12-31

URL:

http://hdl.handle.net/2433/227733

\section{RIGHT:}

(c) 2017. This manuscript version is made available under the CC-BY-NC-ND 4.0 license

http://creativecommons.org/licenses/by-nc-nd/4.0/; The full-text file will be made open to the public on 31 December 2019, in accordance with publisher's 'Terms and Conditions for Self-Archiving'.; This is not the published version. Please cite only the published version.; この論文は出版社版でありません。引用の際には出版社版をご確認で利用ください。 


\title{
Factors affecting oxidative peat decomposition due to land use in tropical peat swamp forests in Indonesia
}

\author{
Masayuki Itoh $^{\mathrm{a}}$, Yosuke Okimoto ${ }^{\mathrm{b}}$, Takashi Hirano ${ }^{\mathrm{b}}$, Kitso Kusin ${ }^{\mathrm{c}}$ \\ ${ }^{a}$ Center for Southeast Asian Studies, Kyoto University, Kyoto 606-8501, Japan \\ ${ }^{b}$ Research Faculty of Agriculture, Hokkaido University, Sapporo 060-8589, Japan \\ ${ }^{\mathrm{c} C I M T R O P, ~ U n i v e r s i t y ~ o f ~ P a l a n g k a r a y a, ~ P a l a n g k a r a y a, ~ 73112, ~ I n d o n e s i a ~}$
}

Corresponding author: Masayuki ITOH

Tel: 81+75-753-9195; Fax:81+75-753-9195; $\quad$ E-mail:masayukiitoh@yahoo.co.jp

\begin{abstract}
The increasing frequency of fire due to drainage of tropical peatland has become a major environmental problem in Southeast Asia. To clarify the effects of changes in land use on carbon dioxide emissions, we measured oxidative peat decomposition (PD) at different stages of disturbance at three sites in Central Kalimantan, Indonesia: an undrained peat swamp forest (UF), a heavily drained peat swamp forest (DF), and a drained and burned ex-forest (DB).

PD exhibited seasonality, being less in the wet season and greater in the dry season.
\end{abstract}


From February 2014 to December 2015, mean PD ( \pm SE) were $1.90 \pm 0.19,2.30 \pm 0.33$, and $1.97 \pm 0.25 \mu \mathrm{mol} \mathrm{m} \mathrm{m}^{-2} \mathrm{~s}^{-1}$ at UF, DF, and DB, respectively. The groundwater level (GWL) was a major controlling factor of PD at all sites. At UF and DF, PD and GWL showed significant quadratic relationships. At DB, PD and GWL showed significant positive and negative relationships during the dry and wet seasons, respectively. Using these relationships, we estimated annual PD from GWL data for 2014 and 2015 as 698 and $745 \mathrm{~g} \mathrm{C} \mathrm{m}^{-2} \mathrm{yr}^{-1}$ at UF (mean GWL: -0.23 and $-0.39 \mathrm{~m}$ ), 775 and $825 \mathrm{~g} \mathrm{C} \mathrm{m}^{-2} \mathrm{yr}^{-1}$ at DF (-0.55 and $-0.59 \mathrm{~m})$, and 646 and $748 \mathrm{~g} \mathrm{C} \mathrm{m}^{-2} \mathrm{yr}^{-1}$ at $\mathrm{DB}-0.22$ and $\left.-0.62 \mathrm{~m}\right)$, respectively. The annual PD was significantly higher in DF than in UF or DB, in both years. Despite the very dry conditions, the annual PD values at these sites were much lower than those reported for tropical peat at plantations (e.g., oil palm, rubber, and acacia). The differences in the relationship between PD and GWL indicate that separate estimations are required for each type of land. Moreover, our results suggest that PD can be enhanced by drainage both in forests and at burned sites.

Keywords: Tropical peat; Land-use change; Drainage; Oxidative peat decomposition; Trenching 


\section{Introduction}

Southeast Asia contains an abundance of peat, found as peat swamp forests (Page et al., 2004), which are distributed predominantly in Indonesia and Malaysia. Indonesia has the largest area of tropical peat in the world, over $2.48 \times 10^{5} \mathrm{~km}^{2}$, accounting for about $56 \%$ of global tropical peatland area; Indonesia's peatland stores up to $68.5 \mathrm{Gt}$ of soil carbon (C), or 77\% of soil C in global tropical peatlands (Page et al., 2011). However, vulnerable peat swamp forest ecosystems have been devastated by extensive logging and land development involving deforestation and drainage since the 1970s (Sorensen, 1993). As a result, large areas of peat swamp forest have been converted into secondary forests, plantations, and abandoned open shrub and fern lands due to repeated peat fires. For example, the amount of open land has increased from $7 \%$ to $15 \%$ of total land area over the last two decades (Miettinen et al., 2012; 2016). Deforestation can raise soil temperatures (Sano et al., 2010), and drainage directly lowers the groundwater level (GWL). Land conversion with deforestation and drainage accelerates oxidative peat decomposition (PD), because of increases in temperature and aeration (Couwenberg et al., 2010; Hooijer et al., 2012). Extensive forest exploitation following peat drainage for agricultural expansion (e.g., the creation of oil palm and acacia plantations) can lead to catastrophic peat fires (Langner and Siegert, 2009; Yulianti et al., 2012). The frequency of fires may explain why the area of abandoned and unused peatland has increased 
threefold from 1.2 to 3.5 Mha since 1990, as landowners have given up on managing their land (Miettinen and Liew, 2010).

Conversion of peatland inevitably leads to aeration and consequent PD, resulting in substantial carbon dioxide $\left(\mathrm{CO}_{2}\right)$ emissions into the atmosphere (e.g., Melling et al., 2005; Couwenberg et al., 2010, 2011; Hooijer et al., 2014; Hirano et al., 2014; Könönen et al., 2015). Annual $\mathrm{C}$ losses through peat drainage and fires are on average 28 times greater than pre-disturbance rates (Dommain et al., 2014). According to the Wetland Supplement (IPCC, 2014), default $\mathrm{CO}_{2}$ emissions from tropical peatlands (i.e., emission factors [EFs]) range from 150 to $2000 \mathrm{~g} \mathrm{C} \mathrm{m}^{-2} \mathrm{y}^{-1}$, although this was determined using limited data from fewer than 50 peer-reviewed papers.

The 2006 Intergovernmental Panel on Climate Change Guidelines (IPCC, 2006) generally provides methods for the estimation of greenhouse gases at three levels of detail, from Tier 1 (the default method) to Tier 3 (the most detailed method). The IPCC offers accurate EFs, but deriving EFs from tropical peatlands is a scientific challenge. The Tier 3 approach is not yet feasible due to a lack of accurate data (Couwenberg and Hooijer, 2013); thus, more field data are required from various types of land use in tropical peatlands (Krisnawati et al., 2015). Therefore, this study included sites representing three types of land use, with different levels of disturbance (minimal, moderate, and intensive) 
due to drainage and repeated forest fires in an edaphically similar area.

Direct chamber measurements have been made to obtain accurate $\mathrm{C}$ loss data from tropical peatland (e.g., Couwenberg et al., 2010; Hooijer et al., 2010, 2012; Jauhiainen et al., 2012; Couwenberg and Hooijer, 2013). However, few studies have reported PD by heterotrophic respiration alone (Jauhiainen et al., 2012; Hirano et al., 2014), separate from peat total soil respiration (SR), including litter decomposition and root respiration (RR). RR may be responsible for various amounts of total SR, from $<10 \%$ to $90 \%$, so SR measurements alone are inadequate for determining $\mathrm{CO}_{2}$ emissions from $\mathrm{PD}$ (Couwenbeg et al., 2010). Few studies have directly measured PD using the chamber technique; these measurements have been taken for tropical peat in an acacia plantation (Jauhiainen et al., 2012), oil palm plantation (Dariah al., 2014; Husnain et al., 2014), mixed forest (Melling et al., 2013), and drained and burned ex-forest (Hirano et al., 2014).

Therefore, we measured PD in three types of tropical peatlands using the closedchamber method with trenching, to exclude root respiration (RR). Then, to understand how the environmental factors affects $\mathrm{CO}_{2}$ fluxes, we compared the results from different types of land use under the same geophysical conditions. Wakhid et al. (2017) recently reported both $\mathrm{PD}$ and SR for compacted peat in a rubber plantation only $25 \mathrm{~km}$ from our observation sites, enabling us to compare our results with data from a plantation. Finally, 
seasonal variation and annual $\mathrm{CO}_{2}$ emissions were estimated using empirical models.

\section{Materials and methods}

\subsection{Study site}

This study was conducted in tropical peatland at the upper Sebangau River Catchment, located about $20 \mathrm{~km}$ south of the city of Palangka Raya, Central Kalimantan province, Indonesia (Fig. 1). A large peatland area was deforested and drained in this province in the late 1990s under the auspices of the national Mega Rice Project. The project was terminated in 1999, but not before it had resulted in vast areas of degraded peatland. Our three study sites were located on flat terrain within $15 \mathrm{~km}$ of each other and included a largely undrained peat swamp forest (UF; $\left.2.32^{\circ} \mathrm{S}, 113.90^{\circ} \mathrm{E}\right)$, a drained peat swamp forest $\left(\mathrm{DF} ; 2.35^{\circ} \mathrm{S}, 114.04^{\circ} \mathrm{E}\right)$, and a drained and burned ex-peat swamp forest $\left(\mathrm{DB} ; 2.34^{\circ} \mathrm{S}, 114.04^{\circ} \mathrm{E}\right)$ that had experienced repeated fires and was characterized by vegetation regrowth dominated by pioneer species such as ferns (Hirano et al., 2012). DB had experienced fires at least four times, in 1997, 2002, 2009, and 2014, which were El Niño years. DF and DB were drained due to the creation of a large canal (width: $25 \mathrm{~m}$, depth: 3.5-4.5 m) excavated in 1996 and 1997 (Page et al., 2009). In addition, smaller canals were constructed near DB in May to June 2014 (during our observation period), with the aim of expanding an oil palm plantation. Notably, in the dry season of October 
2014, a peat fire that approached within a few meters of the study plots occurred at DB.

A strong El Niño event occurred in 2015, and a large forest fire occurred near the study site. The peat depths at UF, DF, and DB were approximately $3.0,4.5$, and $4.5 \mathrm{~m}$, respectively. Further information on each site is available in our previous paper (Hirano et al., 2012).
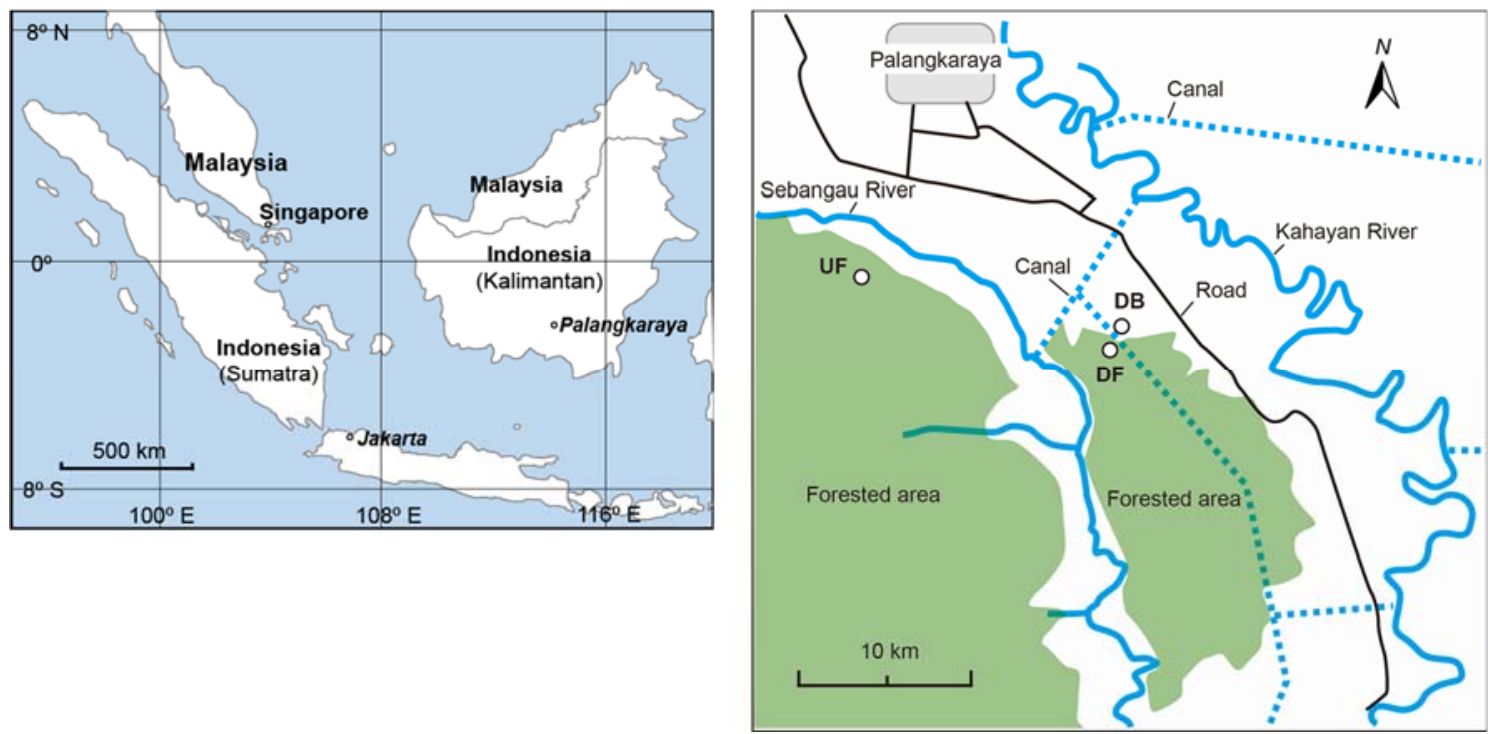

Fig. 1. Locations of Palangkaraya in Central Kalimantan, Indonesia and the research sites.

The annual air temperature over 14 years $(2002-2015)$ was $26.2^{\circ} \mathrm{C} \pm 0.2^{\circ} \mathrm{C}$ (mean

\pm 1 standard deviation [SD]). The annual precipitation for the same period was $2546 \pm$ $466 \mathrm{~mm} \mathrm{yr}^{-1}$, measured on a tower at DF (Hirano et al., 2012).

\subsection{Measurements of groundwater level and soil and air temperatures}

The GWL was measured hourly in perforated PVC pipes as the distance of the 
groundwater from the surface of the ground using a water pressure sensor (HTV-050KP; Sensez, Tokyo, Japan) from January 2014 to December 2015. The soil temperature was measured hourly at a depth of $5 \mathrm{~cm}$, inside a trench, using a temperature logger (Thermochron SL-type; KN Laboratories Inc., Osaka, Japan) in each plot.

\subsection{Peat properties}

Peat soil was sampled in September 2014, when the GWL was at its lowest point during the year. At each site, a pit was dug approximately $80 \mathrm{~cm}$ deep at least $1 \mathrm{~m}$ from any trees. Five replicates of core samples (volume: $100 \mathrm{~cm}^{3}$ ) were collected using sharpened steel cylinders to avoid peat compression. Samples were divided by depth into peat layers of $0-5,10-15,20-25,30-35,50-55$, and $70-75 \mathrm{~cm}$ for UF (apart from the layers 50-55 and 70-75 cm), DF (all), and DB (apart from 70-75 cm) in accordance with the GWL. A total of 90 peat samples were collected and oven-dried at $105^{\circ} \mathrm{C}$ for up to 96 h. The $\mathrm{C}$ and nitrogen $(\mathrm{N})$ contents of the peat soil were determined with a $\mathrm{CN}$ analyzer (Sumigraph NCH-22; Sumika Chemical Analysis Service Ltd., Osaka, Japan).

\subsection{Soil carbon dioxide efflux measurements}

Three trenches were installed within $50 \mathrm{~m}$ from a flux tower at each site in September

2013. Square trenched plots $(1 \mathrm{~m} \times 1 \mathrm{~m})$ were established by making $1 \mathrm{~m}$ deep cuts into 
the ground along the boundaries with a steel knife and using a shovel to sever all roots. For each plot, four $2 \mathrm{~mm}$ thick polyethylene boards $(1.2 \mathrm{~m} \times 1 \mathrm{~m})$ were inserted vertically into the soil to prevent root invasion. All plants were removed from the peat inside the trench before chamber installation. Any fern and sedge plants that had regrown inside the collars and trenches were removed periodically. In addition, leaf litter was removed from the collars before measurement. These precautions ensured that the $\mathrm{CO}_{2}$ efflux of the soil was equivalent to PD, and RR could be completely eliminated. In each trench, 4 PVC collars (diameter: $21 \mathrm{~cm}$, height: $2 \mathrm{~cm}$ ) were placed $3 \mathrm{~cm}$ deep, for a total of 12 collars at each site. The collars had grooves on their tops that allowed them to be filled with water. The $\mathrm{CO}_{2}$ efflux from the peat surface was measured following the closed-chamber method. A portable infrared gas analyzer (GMP343; Vaisala, Helsinki, Finland) was attached to an opaque PVC chamber. The ground-covering area and volume of the chamber headspace were $0.0491 \mathrm{~m}^{2}$ and $0.0074 \mathrm{~m}^{3}$, respectively. The effective volume of the chamber was calculated in accordance with the varying heights of the collar due to soil subsidence and applied to the calculation of $\mathrm{CO}_{2}$ efflux. To shorten response times, the dust filter was detached from the portable infrared gas analyzer. No fans were used to mix the air in the chamber, but the air in the chamber headspace was replaced with ambient air using a fan before each measurement. 
Soil $\mathrm{CO}_{2}$ effluxes from microbial PD were measured three times a day, at 10:00, 11:30, and 14:00, midway through each month. After trench installation in September 2013, we waited until the start of February 2014 to begin measurements to minimize the effects of the decomposition of recently killed roots, which could contribute to overestimations of PD (Sulzman et al., 2005). During the measurements, the chamber was placed securely over the chamber collar. The chamber was kept airtight by filling the collar groove with water. $\mathrm{CO}_{2}$ concentrations were measured every $5 \mathrm{~s}$ over 3 min and recorded using a data logger (LR5042; Hioki, Nagano, Japan). The rate of increase of the $\mathrm{CO}_{2}$ was calculated with linear fitting using the least-squares method. The $\mathrm{CO}_{2}$ analyzer was calibrated every three months using standard gases at two $\mathrm{CO}_{2}$ concentrations. The monthly measurements began in February 2014 and lasted until December 2015. If measurements could not be performed due to heavy rain, we took the results of another sample or the average of two samples on the sampling date. In addition, we could not conduct measurements in October 2014 for sites DF and DB and in October 2015 for all sites because of an expanding peat fire and an analyzer malfunction, respectively. During the waterlogged period, we doubled the chamber collar to increase the measurement height. Air temperatures in the chamber headspace were measured every $5 \mathrm{~s}$ using a temperature logger (LR5011, Hioki), and soil temperatures were measured at a depth of 
$5 \mathrm{~cm}$ using a digital thermometer at each plot. The efflux of soil $\mathrm{CO}_{2}\left(\mu \mathrm{mol} \mathrm{mol} \mathrm{m}^{-1} \mathrm{~m}^{-2} \mathrm{~s}^{-}\right.$

${ }^{1}$ ) was calculated using the air temperature and the increasing rate of $\mathrm{CO}_{2}$ concentration $\left(\mathrm{dC} / \mathrm{dt}, \mu \mathrm{mol} \mathrm{s}{ }^{-1}\right)$ using Eq. (1):

$\mathrm{CO}_{2}$ efflux $\left.=(d C / d t) *\left(V / V^{\prime}\left(273.2+T_{a}\right) / 273.2\right)\right) / A$

where $\mathrm{V}$ is the effective chamber volume $\left(\mathrm{m}^{3}\right), \mathrm{V}^{\prime}$ is the molar volume of air at $0^{\circ} \mathrm{C}$ $\left(0.0224 \mathrm{~m}^{3} \mathrm{~mol}^{-1}\right)$, and $\mathrm{A}$ is the ground area covered by the chamber $\left(\mathrm{m}^{2}\right)$. A linearity test was applied to assess the quality of $\mathrm{dC} / \mathrm{dt}$, following the approach of Aguilos et al. (2013).

Statistical tests were performed using R ver. 3.3.1 (R Development Core Team, 2016).

Differences among the treatment groups were analyzed using analysis of variance, and specific differences among groups were analyzed using Tukey's multiple comparison test.

\section{Results}

\subsection{Seasonal variation in environmental factors}

The levels of annual precipitation in 2014 and 2015 were 2199 and $2380 \mathrm{~mm} \mathrm{yr}^{-1}$, respectively, 13.6\% and 6.5\% lower than the 14-year average from 2002 to 2015 (Fig. 2a). The dry season lasted for 3-4 months, from June or July, based on the commonly used criterion of monthly precipitation less than $100 \mathrm{~mm}$ (e.g., Malhi and Wright, 2004). These long dry seasons, particularly that of 2015, were probably caused by strong El Niño events (Schiermeier, 2015). 
GWL began to decrease at the beginning of the dry period (mid-July in 2014 and early August in 2015) and remained low until the end of the dry period (mid-November in 2014 and late October in 2015). The dry season of 2014 was longer than that of 2015, although maximum drawdown of the GWLs at all sites was greater in 2015 than 2014 (Fig. 2a, 2c). GWLs began to increase with the onset of the rainy season and peaked in late April in 2014 and mid-March in 2015. The lowest GWLs at UF, DF, and DB in 2015 were $-1.43,-1.62$, and $-1.52 \mathrm{~m}$, respectively (Fig. 2c). Mean annual GWLs in both observation years were much lower than the 11-year mean GWLs (2005-2015) at all sites: DF, -0.55 m (2014), -0.59 m (2015), and -0.47 m (11-year mean); UF, -0.23 m (2014), $0.39 \mathrm{~m}$ (2015; lowest in 11 years), and -0.15 m (11-year mean); and DB, -0.22 m (2014), $-0.63 \mathrm{~m}$ (2015; lowest in 11 years), and $-0.14 \mathrm{~m}$ (11-year mean). Comparing the 2 observation years, mean GWLs were lower in 2015 than in 2014 at all three sites, due to the prolonged dry season caused by a strong El Niño event in 2015. Furthermore, the much lower GWL in 2015 at DB was exacerbated by a newly constructed drainage canal for an oil palm plantation near DB around June 2014. The GWL was lower at DF than at DB in 2014, but they were almost the same in 2015, probably due to the effects of the new canal. The GWL at DF was lower than the levels at UF and DB $\left(p<10^{-7}\right)$ in 2014, but a significant difference was only observed between the levels at DF and UF in 2015. 
The daily mean soil temperatures at a depth of $5 \mathrm{~cm}$ were $26.2^{\circ} \mathrm{C}, 26.1^{\circ} \mathrm{C}$, and $28.7^{\circ} \mathrm{C}$ at UF, DF, and DB, respectively. The highest soil temperature was recorded at DB, reaching a maximum of $31.2^{\circ} \mathrm{C}$. The soil temperature at $\mathrm{DB}$ was significantly higher than temperatures at the other two sites $\left(p<10^{-10}\right)$, because DB was more exposed to solar radiation during the day due to its sparser vegetation cover. Soil temperatures at DF and UF were similar $(p>0.05)$, and never exceeded $30^{\circ} \mathrm{C}$ (Fig. $2 b$ ). 

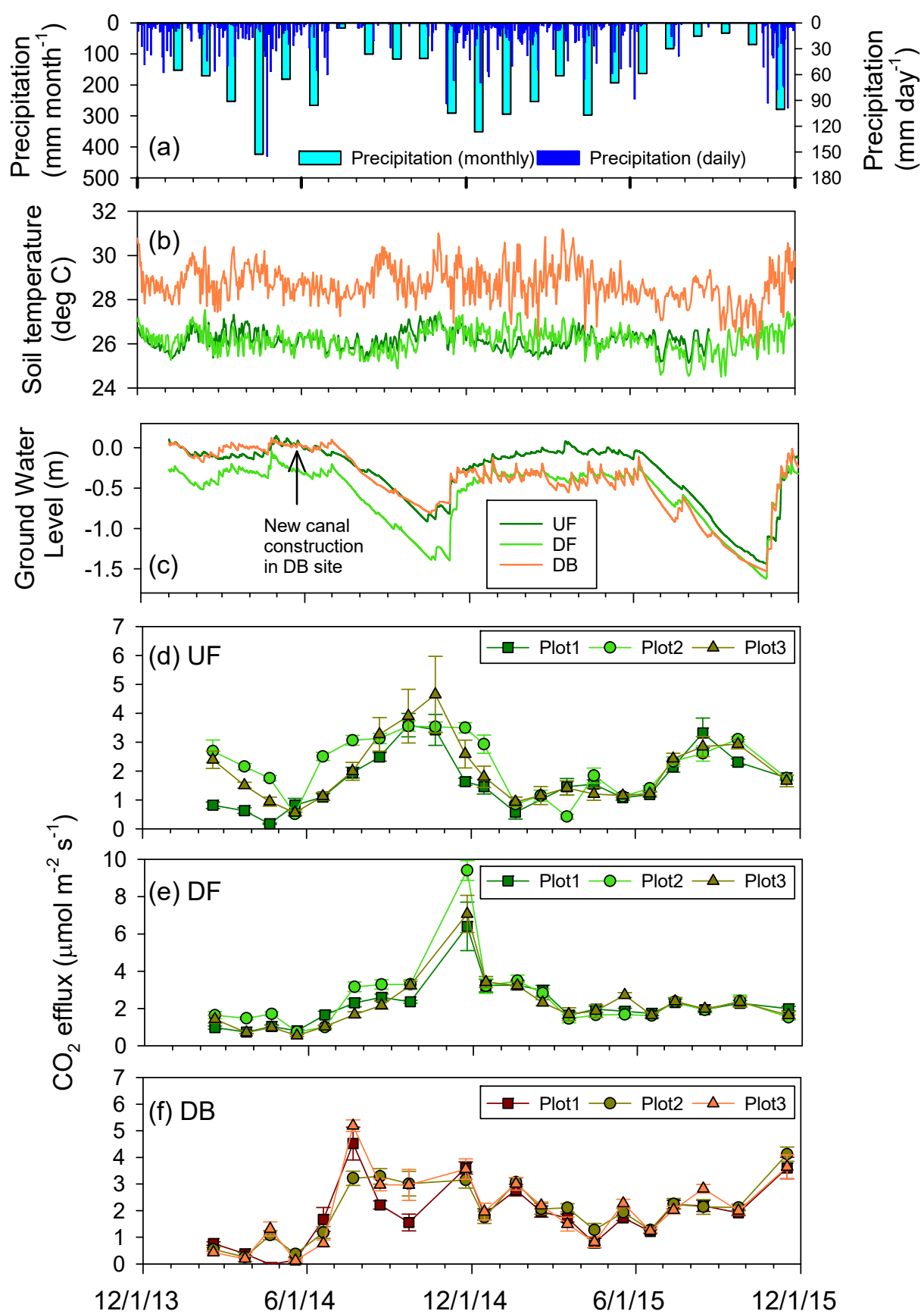

Fig. 2. Seasonal variation in (a) daily and monthly precipitation at drained and burned forest [DB], (b) daily mean soil temperature at a depth of $5 \mathrm{~cm}$, (c) daily mean groundwater level, and (d), (e), (f), $\mathrm{CO}_{2}$ efflux at each sampling plot (mean $\pm \mathrm{SE}$ ) at the study sites, undrained forest [UF], drained forest [DF], and DB, respectively. 


\subsection{Carbon and nitrogen content and bulk density of peat}

There was no obvious difference in bulk density among sampling depths at UF and

DF (Table 2). By contrast, bulk density in the surface layer $(0-5 \mathrm{~cm})$ was significantly higher than in the deeper layers at DB $\left(p<10^{-8}\right.$; Table 1$)$. The bulk density in the surface layer at DB was almost two times higher than those at UF and DF. The C content gradually increased with depth at UF, whereas it remained almost the same at all depths at the other sites, apart from the 30-35 cm layer at DF (Table 1). The $\mathrm{C}$ content in the $0-5 \mathrm{~cm}$ layer was significantly higher at DB $\left(p<10^{-3}\right.$; Table 1$)$. The $\mathrm{N}$ content gradually decreased with depth at all sites. In deeper layers, the $\mathrm{N}$ content was much lower at DF and DB than at UF. The $\mathrm{N}$ content at UF remained above $1.4 \%$ until a depth of $45 \mathrm{~cm}$, which was similar to the results of Lampera et al. (2014). By contrast, it fell below 1\% at depths of $30 \mathrm{~cm}$ and $10 \mathrm{~cm}$ at $\mathrm{DF}$ and $\mathrm{DB}$, respectively. The three sites had different $\mathrm{C} / \mathrm{N}$ ratio profiles: the UF site had the lowest ratios, followed by $\mathrm{DF}$ and then $\mathrm{DB}$. The $\mathrm{C} / \mathrm{N}$ ratio at DB was much higher than those of the other two sites; it was 41.9 in the surface layer and exceeded 60 in layers below a depth of $10 \mathrm{~cm}$ (Table 1). 
Table 1. Main characteristics of the peat at the study sites (mean $\pm \quad \mathrm{SD}, n=5$ ).

\begin{tabular}{cccccc}
\hline Site & $\begin{array}{c}\text { Sampling } \\
\text { depth } \\
(\mathrm{cm})\end{array}$ & $\begin{array}{c}\text { Bulk density } \\
\left(\mathrm{g} \mathrm{cm}^{-3}\right)\end{array}$ & $\begin{array}{c}\text { C content } \\
(\%)\end{array}$ & $\begin{array}{c}\text { N content } \\
(\%)\end{array}$ & $\mathrm{C} / \mathrm{N}$ \\
& $0-5$ & $0.11 \pm 0.01$ & $49.9 \pm 0.2$ & $1.90 \pm 0.07$ & $26.3 \pm 0.8$ \\
& $10-15$ & $0.11 \pm 0.00$ & $50.3 \pm 0.5$ & $1.82 \pm 0.08$ & $27.7 \pm 2.2$ \\
UF & $15-20$ & $0.09 \pm 0.00$ & $51.5 \pm 0.5$ & $1.76 \pm 0.10$ & $29.3 \pm 2.0$ \\
& $20-25$ & $0.09 \pm 0.01$ & $51.7 \pm 1.2$ & $1.62 \pm 0.19$ & $32.3 \pm 3.8$ \\
& $30-35$ & $0.10 \pm 0.01$ & $52.6 \pm 0.9$ & $1.41 \pm 0.16$ & $37.6 \pm 4.6$ \\
& $40-45$ & $0.10 \pm 0.01$ & $54.0 \pm 1.5$ & $1.42 \pm 0.03$ & $38.1 \pm 0.6$ \\
\hline & $0-5$ & $0.14 \pm 0.01$ & $50.3 \pm 0.3$ & $1.60 \pm 0.07$ & $31.5 \pm 1.3$ \\
& $10-15$ & $0.13 \pm 0.01$ & $54.6 \pm 1.4$ & $1.63 \pm 0.05$ & $33.5 \pm 1.9$ \\
& $20-25$ & $0.10 \pm 0.01$ & $55.0 \pm 0.5$ & $1.37 \pm 0.03$ & $40.1 \pm 1.2$ \\
& $30-35$ & $0.16 \pm 0.01$ & $63.5 \pm 1.1$ & $0.91 \pm 0.10$ & $70.7 \pm 7.6$ \\
& $50-55$ & $0.14 \pm 0.01$ & $53.0 \pm 3.5$ & $0.77 \pm 0.09$ & $69.5 \pm 4.9$ \\
& $70-75$ & $0.12 \pm 0.01$ & $54.8 \pm 1.5$ & $0.95 \pm 0.31$ & $62.7 \pm 18.3$ \\
\hline & $0-5$ & $0.24 \pm 0.02$ & $54.4 \pm 1.8$ & $1.30 \pm 0.10$ & $41.9 \pm 2.0$ \\
& $10-15$ & $0.14 \pm 0.01$ & $53.5 \pm 1.8$ & $0.85 \pm 0.06$ & $63.0 \pm 4.1$ \\
& $20-25$ & $0.14 \pm 0.01$ & $51.8 \pm 2.1$ & $0.82 \pm 0.05$ & $63.2 \pm 3.9$ \\
& $30-35$ & $0.14 \pm 0.01$ & $55.1 \pm 4.0$ & $0.78 \pm 0.07$ & $70.8 \pm 7.3$ \\
& $50-55$ & $0.11 \pm 0.00$ & $53.4 \pm 2.7$ & $0.74 \pm 0.07$ & $72.8 \pm 4.3$ \\
\hline
\end{tabular}

\subsection{Seasonal variation in oxidative peat decomposition}

Because there were no significant differences in PD among the three daily sampling times at each sampling plot throughout the sampling period $(p>0.05)$, the daily average PD value for each sampling plot was used for further analysis. Figure $2 d-f$ shows the seasonal variation in mean $\mathrm{CO}_{2}$ efflux in the three plots at $\mathrm{UF}, \mathrm{DF}$, and $\mathrm{DB}$ (mean of the maximum measurements for 12 chambers, which means 4 chambers, three times for each observation date), respectively, from February 2014 to December 2015. PD exhibited 
seasonality and was lower in the wet (high-GWL) season and higher in the dry (lowGWL) season. A much larger $\mathrm{CO}_{2}$ efflux $\left(7.63 \pm 0.90 \mu \mathrm{mol} \mathrm{m}^{-2} \mathrm{~s}^{-1}\right)$ was observed on 24 November 2014 at DF, which occurred immediately after rainfall during the dry period. The mean PD values (mean \pm standard error) for the entire sampling period were $1.66 \pm$ $0.21,2.18 \pm 0.22$, and $1.88 \pm 0.19 \mu \mathrm{mol} \mathrm{m}^{-2} \mathrm{~s}^{-1}$, at plots 1,2 , and 3, respectively, at UF. At DF and DB, the mean PD values were $2.20 \pm 0.27,2.49 \pm 0.41$, and $2.21 \pm 0.31 \mu \mathrm{mol}$ $\mathrm{m}^{-2} \mathrm{~s}^{-1}$ and $1.84 \pm 0.26,2.01 \pm 0.24$, and $2.05 \pm 0.29 \mu \mathrm{mol} \mathrm{m} \mathrm{m}^{-2} \mathrm{~s}^{-1}$ at plots 1,2 , and 3 , respectively. Excluding the large $\mathrm{CO}_{2}$ efflux in November 2014 at DF, the mean PD values were $1.98 \pm 0.17,2.13 \pm 0.19$, and $1.95 \pm 0.19 \mu \mathrm{mol} \mathrm{m}^{-2} \mathrm{~s}^{-1}$ at plots 1,2 , and 3 , respectively. These values are much lower than those at a rubber plantation developed after peat compaction $\left(5.96 \pm 0.43 \mu \mathrm{mol} \mathrm{m} \mathrm{m}^{-2} \mathrm{~s}^{-1}\right.$ with a mean bulk density of $0.23 \mathrm{~g} \mathrm{~cm}^{-3}$ from the surface to $70 \mathrm{~cm}$ depth) in the same region (Wakhid et al., 2016). There were no significant differences in annual mean PD between the sampling years (2014 and 2015) at all sites $(p>0.05)$, apart from UF Plot $2(2015>2014, p=0.02)$. PD at DB was significantly larger $(p<0.013)$ after canal excavation at all sampling plots in the wet season (December-June).

\subsection{Relationship of PD with GWL and prediction of PD}

The relationship between PD and GWL showed a significant quadratic correlation in 
all sampling plots at both UF and DF (Fig. 3a and b). A large $\mathrm{CO}_{2}$ efflux in November 2014 at DF was removed from the correlation analysis, because rewetting can temporarily enhance decomposition or respiration during a dry period (as detailed in Ishikura et al., 2017). At DB, PD peaked at the beginning of the dry period and decreased with decreasing GWL until GWL reached a depth of $-1.4 \mathrm{~m}$. By contrast, PD increased with decreasing GWL in the wet season, when there was a relatively high GWL (Fig. 3d). In both periods, PD was linearly correlated with GWL at all sampling plots. There were significant but weak positive relationships between PD and soil temperature at one of the three plots at UF and all three plots at DB during the dry period $(p<0.05)$. No significant correlation was observed between PD and soil temperature in all plots at DF $(p>0.05)$.

These results suggest that GWL acted as a major controlling factor for seasonal variation in PD. This is consistent with many reports from tropical peatlands, including Sundari et al. (2012) and Hirano et al. (2014), with data from the same study sites. Thus, we predicted PD from GWL using the following correlation equation for UF and DF:

$$
P D=a * G W L^{2}+b * G W L+c
$$

and separately for DB for the dry and wet seasons:

$$
P D=a * G W L+c
$$

where PD is the prediction of the daily average oxidative PD $\left(\mu \mathrm{mol} \mathrm{CO}_{2} \mathrm{~m}^{-2} \mathrm{~s}^{-1}\right), \mathrm{GWL}$ 
is the daily average groundwater level from the ground surface (m), and $a, b$, and $c$ are coefficients. For DF, the predicted PD was lower than measurements when the GWL exceeded $-0.5 \mathrm{~m}$ (Fig. 3b), leading to underestimation of the annual PD. Because the larger PD was observed just after the long dry season in 2014, we assumed that continuous dry conditions had some effects on PD, even in the following wet season. Therefore, we also tried to predict PD from the 1-, 2-, 3-, and 4-month mean GWL before each sampling date. This revealed that the 3-month mean antecedent GWL best-explained PD, having the highest coefficient of determination $\left(r^{2} ;\right.$ Fig. 3c). For DB, we used different $a$ and $c$ values for the dry and wet seasons, with reference to the periods during which GWL decreased and increased. The results of the regression analyses revealed significant correlations between predicted PD and observed PD at all sites and plots (UF: Plots 1, 2, and $3 ; F_{1,53}=151.7, p<10^{-16}, F_{1,55}=49.6, p<10^{-8}, F_{1,54}=124.7, p<10^{-14}$; DF: Plot 1 , 2 , and $3 ; F_{1,54}=7.6, p=0.008, F_{1,54}=16.8, p=0.0001, F_{1,54}=11.4, p=0.001 ; \mathrm{DF}(3-$ month mean GWL) : Plot 1, 2, and 3; $F_{1,54}=25.0, p<10^{-5}, F_{1,54}=31.0, p<10^{-6}, F_{1,54}=$ 45.4, $p<10^{-7}$; DB: Plot 1,2 , and 3; $F_{1,49}=115.8, p<10^{-13}, F_{1,49}=108.9, p<10^{-13}, F_{1,48}$ $=130.5, p<10^{-14}$ ) (Fig. 4). Table 2 lists the fit parameters in Eqs. (2) and (3) for each sampling plot. 


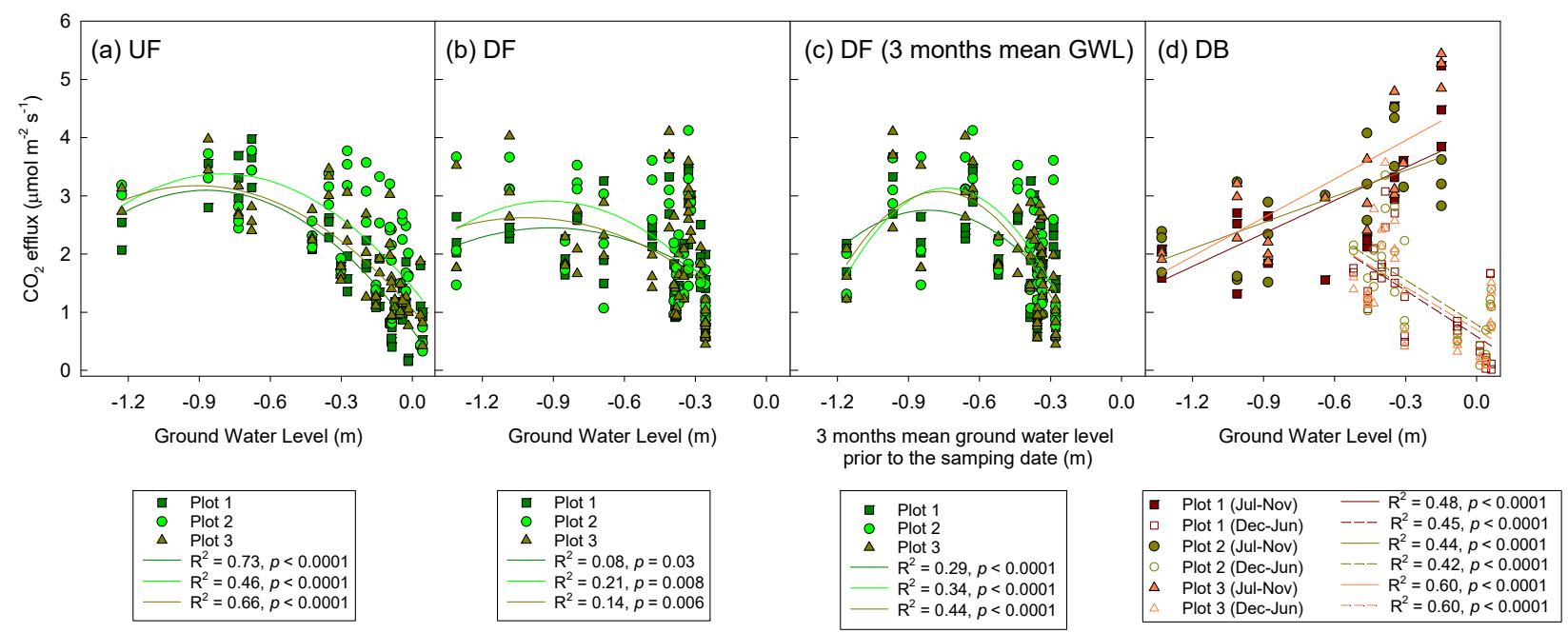

Fig. 3. Relationship between $\mathrm{CO}_{2}$ efflux (PD) and GWL at (a) UF, (b) DF, (c) DF with 3month mean GWL before each sampling date, and (d) DB. Quadratic curves were fitted for UF and DF. Linear regression was applied separately for the dry (July-November) and wet (December-June) seasons at DB. 


\section{है}
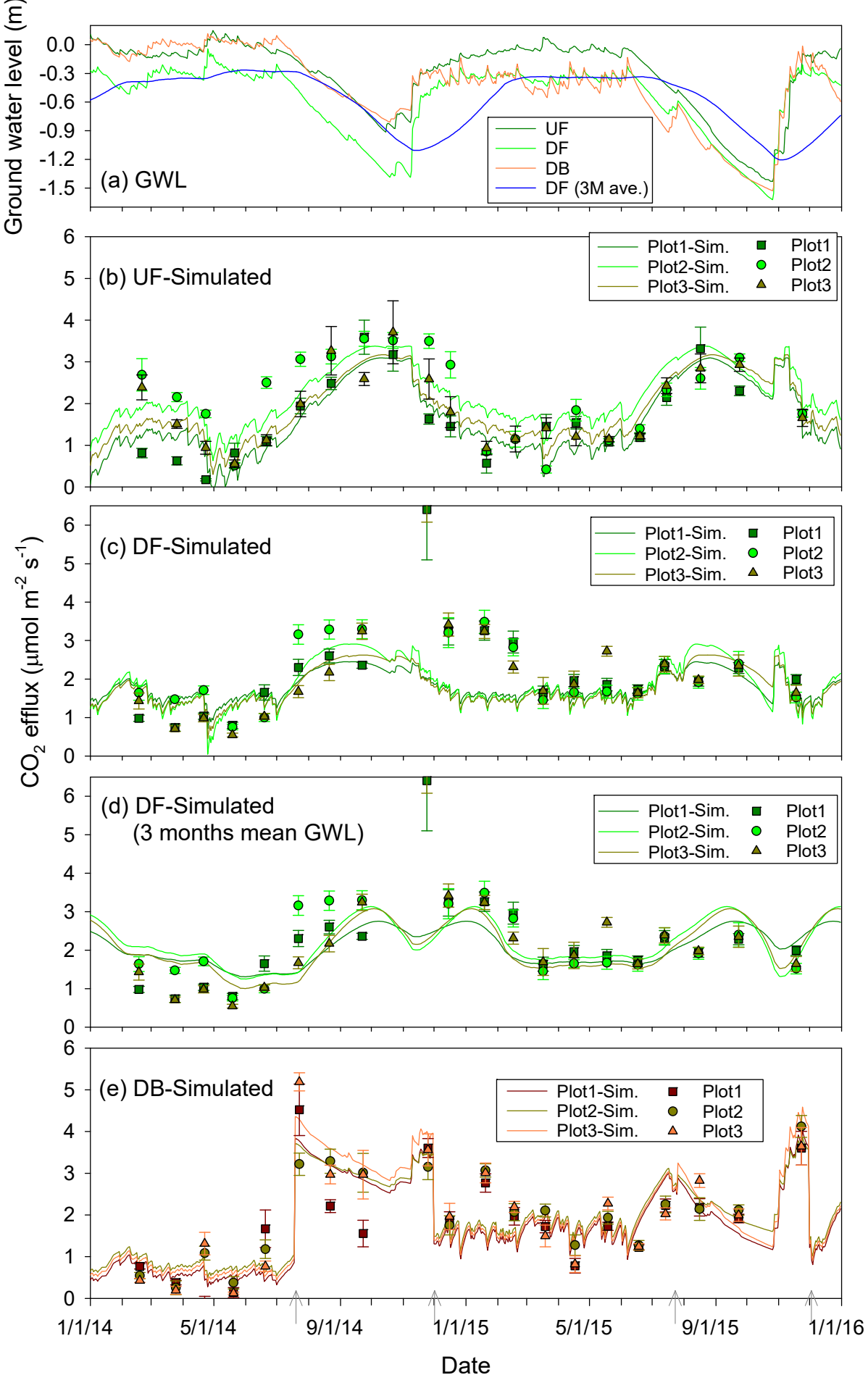

Fig. 4 Results of the prediction of $\mathrm{CO}_{2}$ efflux from oxidative peat decomposition (b-e) with seasonal variation in the daily mean groundwater level $(b, c, e)$ and 3 month mean groundwater level before the predicted date (d). The measured values are shown as symbols (mean $\pm \mathrm{SE}$ ). The arrows in (e) indicate the change between the dry and wet season. 
Table 2. Fit parameters used in Eqs. (2) and (3).

* indicates parameters used in Eq. (2) using the 3-month mean antecedent groundwater level.

\begin{tabular}{clll}
\hline & $a$ & $b$ & $c$ \\
\hline UF (Plot 1) & -3.17 & -5.51 & 0.69 \\
(Plot 2) & -3.04 & -4.87 & 1.43 \\
(Plot 3) & -2.57 & -4.67 & 1.05 \\
DF (Plot 1) & -1.93 & -3.52 & 0.84 \\
(Plot 2) & -3.13 & -5.74 & 0.27 \\
(Plot 3) & -1.95 & -3.97 & 0.61 \\
DF (Plot 1)* & -4.76 & -7.76 & -0.41 \\
(Plot 2)* & -8.37 & -12.4 & -1.44 \\
(Plot 3)* & -8.16 & -12.5 & -1.74 \\
DB (Plot 1: Dry) & 1.88 & - & 4.05 \\
(Plot 2: Dry) & 1.49 & - & 3.88 \\
(Plot 3: Dry) & 2.21 & - & 4.62 \\
DB (Plot 1: Wet) & -2.64 & - & 0.58 \\
(Plot 2: Wet) & -2.54 & - & 0.79 \\
(Plot 3: Wet) & -2.45 & - & 0.69 \\
\hline
\end{tabular}

\subsection{Estimation of annual $\mathrm{CO}_{2}$ emissions from oxidative peat decomposition}

$\mathrm{CO}_{2}$ emissions were estimated from the predicted PD values derived from Eq. (2) for

UF and DF and from Eq. (3) for DB using the daily mean GWL; the estimations were summed as annual emissions. Table 3 shows the annual estimates of PD for the three sampling plots and the average PD at the three sites for the 2 observation years. For DF, PD was estimated from the 3-month mean GWL before the sampling date. The results revealed a significantly higher mean PD in 2015 than in 2014 at UF Plot $1(p=0.02)$ and UF Plot $3(p=0.006)$, DF Plot $1(p=0.0003)$, DF Plot $2(p=0.003)$, DF Plot $3(p=$ 
0.0008), and DB Plot $1\left(p<10^{-4}\right)$, DB Plot $2\left(p<10^{-6}\right)$, and DB Plot $3(p=0.01)$.

Table 3. Annual mean and sum of $\mathrm{CO}_{2}$ efflux from oxidative peat decomposition predicted from groundwater level in 2014 and 2015. 3-month mean antecedent GWL was used for prediction for DF.

\begin{tabular}{|c|c|c|c|c|c|c|}
\hline \multirow[t]{2}{*}{$\begin{array}{l}\text { Site and } \\
\text { plot }\end{array}$} & \multicolumn{2}{|c|}{$\begin{array}{l}\text { Mean and lowest GWL } \\
\text { (m) }\end{array}$} & \multicolumn{2}{|c|}{$\begin{array}{l}\text { Mean } \mathrm{CO}_{2} \text { efflux } \\
\left(\mu \mathrm{mol} \mathrm{m} \mathrm{m}^{-2} \mathrm{~s}^{-1}\right)\end{array}$} & \multicolumn{2}{|c|}{$\begin{array}{l}\text { Annual } \mathrm{CO}_{2} \text { emissions } \\
\qquad\left(\mathrm{g} \mathrm{C} \mathrm{m}^{-2} \mathrm{y}^{-1}\right)\end{array}$} \\
\hline & 2014 & 2015 & 2014 & 2015 & 2014 & 2015 \\
\hline UF mean & & & $1.84 \pm 0.30$ & $1.97 \pm 0.27$ & $698 \pm 114$ & $745 \pm 99$ \\
\hline Plot 1 & -0.23 & -0.39 & $1.56 \pm 0.87$ & $1.71 \pm 0.83$ & 591 & 648 \\
\hline Plot 2 & -0.91 & -1.43 & $2.16 \pm 0.73$ & $2.23 \pm 0.64$ & 818 & 847 \\
\hline Plot 3 & & & $1.80 \pm 0.76$ & $1.96 \pm 0.75$ & 683 & 740 \\
\hline DF mean & & & $2.05 \pm 0.08$ & $2.18 \pm 0.07$ & $775 \pm 29$ & $825 \pm 26$ \\
\hline Plot 1 & -0.55 & -0.59 & $2.01 \pm 0.49$ & $2.13 \pm 0.42$ & 760 & 806 \\
\hline Plot 2 & -1.39 & -1.62 & $2.14 \pm 0.57$ & $2.26 \pm 0.54$ & 808 & 854 \\
\hline Plot 3 & & & $2.00 \pm 0.65$ & $2.15 \pm 0.58$ & 756 & 814 \\
\hline DB mean & & & $1.70 \pm 0.11$ & $1.98 \pm 0.10$ & $646 \pm 41$ & $748 \pm 37$ \\
\hline Plot 1 & -0.22 & -0.62 & $1.59 \pm 1.20$ & $1.87 \pm 0.63$ & 601 & 707 \\
\hline Plot 2 & -0.81 & -1.53 & $1.73 \pm 1.11$ & $2.05 \pm 0.57$ & 655 & 779 \\
\hline Plot 3 & & & $1.80 \pm 1.34$ & $2.01 \pm 0.73$ & 683 & 759 \\
\hline
\end{tabular}

\section{Discussion}

\subsection{Factors affecting oxidative peat decomposition}

Higher soil temperatures have been reported to enhance SR in tropical peatland (e.g.,

Melling et al., 2005; Ali et al., 2006; Ishikura et al., 2017); however, our results showed only a weak positive correlation between PD and soil temperature $(p<0.05)$ at $\mathrm{DB}$, which lacked a canopy. Moreover, our results suggest that PD could predominantly be explained 
by variation in GWL. There was less precipitation than the average in the 2 observation years, resulting in a lower GWL in the dry season than usual. The relationships between PD and GWL and their regression parameters differed among the study sites (Fig. 3). The $r^{2}$ was greater at UF (Fig. 3a) than DF (Figs. 3b and 3c). PD at UF increased with decreasing GWL and peaked at a GWL between -0.6 and $-0.9 \mathrm{~m}$. A similar pattern was reported by Sundari et al. (2012), who found an increase in total SR with decreasing GWL in many chambers at their UF site. Peat at our undisturbed UF site, with a lower bulk density and greater porosity (Table 1), probably contributed to high water permeability and gas transport (oxygen and $\mathrm{CO}_{2}$ ) under low-GWL conditions, resulting in the greater correlation between PD and GWL. The greater PD at Plot 2 than the other two plots at UF, even during high-GWL conditions, could be explained by its higher elevation (Fig. 3a) than that of the other two plots.

In contrast, $r^{2}$ values at DF with GWL on the sampling date were much lower (Fig. 3b). During the 2 observation years (2014 and 2015), the GWL remained below the peat surface even during the wet season at DF. PD in the peat layer above the GWL remained high even during the high-GWL period, resulting in an unclear relationship between PD and daily GWL. In addition, there were large discrepancies between the measurements and predictions during the post-dry period in 2014 (Fig. 4c), implying that other factors besides GWL enhanced PD after the dry period in 2014. Ishikura et al. (2017) examined the larger SR rate during the rewetting period in cropland on tropical peatland. They 
considered that the decomposition of labile organic matter derived from dead microbes and that the modification of organic matter during dry periods (Birch 1958; Marumoto et al., 1977; van Gestel et al., 1993) contributed to the enhanced $\mathrm{CO}_{2}$ emissions. Under nonwaterlogged conditions, even in the early rainy season, the enhancement of PD by rewetting of surface peat likely contributed to greater $\mathrm{CO}_{2}$ emissions (Figs. 2c and 2e). Using the 3-month mean antecedent GWL, a high PD during the post-dry period was predicted (i.e., with higher $r^{2}$ values; Figs. 3c and 4d). This recorded effect of dryness implies that PD in the surface layer remained at a higher level after the longer dry period than in a normal year (especially in 2014). This explanation was supported by the results of Kwon et al. (2013), who conducted peat incubation experiments under dry conditions, and suggests that more $\mathrm{CO}_{2}$ was emitted due to peat oxidation from drained tropical peat than from pristine peat for the same GWL, because oxidative enzymic activities were enhanced by drainage. Therefore, PD was larger in DF than UF in both 2014 and 2015 (p $<0.001)$. This phenomenon seems to be typical of a site where the peat surface seldom experiences waterlogged conditions and is oxidized consequently, even during the wet period. However, more intensive observation is needed to confirm this hypothesis.

The predicted PD in DB was significantly smaller than in DF in both 2014 and 2015 $(p<0.01)$. The range in the observed PD at DB did not differ significantly from the other two sites, although the soil temperature at DB was significantly higher. Considering that higher soil temperatures enhances decomposition, this implies that potential decomposition was lower at $\mathrm{DB}$, which can probably be attributed to its less-aerobic conditions, higher bulk density, and lower nutrient conditions (i.e., high $\mathrm{C} / \mathrm{N}$ ), particularly 
in surface peat, than in the other two sites (Table 1). The result is consistent with a study by Könönen et al. (2016) conducted in the same area. That study found that surface peat in an open burnt site contained fewer labile compounds (hemicelluloses, extractives, uronic acids, and cellulose) and more recalcitrant acid insoluble lignin than a forest site. The seasonal pattern in PD at DB differed from the other sites, with a peak early in the dry period, when the GWL began to lower, particularly in 2014 (Fig. 2f). There were differences in the physical and chemical characteristics between the pre- (UF and DF) and post-burned (DB) sites. This difference was attributable to the decreased water and gaseous permeability due to the higher bulk density of the surface layer (Table 2) after peat fires. Surface peat, with its low porosity, can function as a gas transport barrier between the atmosphere and deeper peat layers, particularly during periods with higher GWLs, because the pores are filled with water. Decreases in the GWL after the waterlogged conditions of July 2014 probably ended the barrier effect, accelerating surface PD. In the same period in 2015, we did not observe a PD peak. The lower GWL due to the newly excavated drainage canal probably contributed to maintaining greater PD $(p<0.013)$ even during the wet season (December 2014 to June 2015) than in the previous year. However, PD decreased with decreasing GWL below around -0.5 m (Fig. 3d). This phenomenon may be explained by the characteristics of the peat at $\mathrm{DB}$, given 
that a lower gas permeability would prevent oxygen transport to deeper peat layers and that some of the readily decomposable fresh litter had been burned (Christian et al., 2003). This latter explanation is supported by the much lower $\mathrm{N}$ content and higher $\mathrm{C} / \mathrm{N}$ ratio at DB than at the other two sites (Table 1). Soil organic matter with $\mathrm{C} / \mathrm{N}$ ratios greater than 20 typically requires additional $\mathrm{N}$ to support decomposition (Snyder et al. 2009). As a result, an enhancement in microbial PD in deeper peat layers cannot be expected even during the dry period in burned peat sites. These factors may explain the different response of PD to variation in GWL at DB from the response in the other sites (Figs. 3d and $4 \mathrm{e})$.

Wakhid et al. (2017) showed a clear relationship between GWL and PD in a nearby rubber plantation established using heavy machinery after peat compaction; their study site was located $25 \mathrm{~km}$ from ours. In their results, the $\mathrm{CO}_{2}$ efflux from PD increased linearly with decreasing GWL $\left(r^{2}=0.94-0.98\right)$. Our results showed different relationships with GWL than theirs did, probably because of the higher bulk density (around $0.23 \mathrm{~g}$ $\mathrm{cm}^{-3}$ from $0-75 \mathrm{~cm}$ depth) at the plantation site and more vertically homogenized peat conditions, due to peat compaction. By contrast, at our sites, the peat was more porous and the topographic conditions were more heterogeneous, with hollows and hummocks, at UF and DF, while DB had a relatively uneven surface due to the burned peat. The small- 
scale hydrology at our non-plantation sites likely affected PD (e.g., Hirano et al., 2009;

Page et al., 2009; Sundari et al., 2012; Jauhiainen et al., 2012, 2014; Hirano et al., 2014).

This comparison suggests that PD can be predicted more easily at plantations than at noncompacted natural peat sites. 
Table 4. Comparison of annual carbon dioxide emissions from oxidative peat decomposition with previous studies using the chamber method (revised from Wakhid et al., 2017).

\begin{tabular}{|c|c|c|c|c|c|c|c|c|c|}
\hline Type of land use & $\begin{array}{l}\mathrm{CO}_{2} \\
\text { emission } \\
\left(\mathrm{g} \mathrm{C} \mathrm{m}^{-2} \mathrm{y}^{-1}\right)\end{array}$ & $\begin{array}{l}\text { Mean GWL } \\
(\mathrm{m})\end{array}$ & $\begin{array}{l}\text { Bulk } \\
\text { density } \\
\left(\mathrm{g} \mathrm{cm}^{-3}\right)\end{array}$ & $\begin{array}{l}\mathrm{C}^{* *} \\
(\%)\end{array}$ & $\begin{array}{l}\mathrm{N}^{* *} \\
(\%)\end{array}$ & $\begin{array}{l}\text { Fertilizer } \\
* * *\end{array}$ & $\begin{array}{l}\text { Treatment } \\
* * * *\end{array}$ & Reference & Note $\dagger$ \\
\hline Oil palm plantation & 1042 & -0.52 & 0.16 & 45 & 1.5 & $\mathrm{Y}$ & I & Dariah et al., 2014 & Jambi, ID (6 years) \\
\hline Oil palm plantation & 930 & -1.14 & 0.19 & 49 & 2.1 & $\mathrm{Y}$ & I & Dariah et al., 2014 & Jambi, ID (15 years) \\
\hline Oil palm plantation & 1800 & -0.72 & NA & NA & NA & $\mathrm{Y}$ & I & Husnain et al., 2014 & Riau, ID \\
\hline Oil palm plantation & 693 & -0.58 & 0.20 & 46 & 1.8 & $\mathrm{Y}$ & $\mathrm{T}$ & Melling et al., 2013 & Sarawak, MY \\
\hline Acacia plantation & 2182 & -0.80 & 0.09 & NA & NA & NA & $\mathrm{T} \& \mathrm{I}$ & Jauhiainen et al., 2012 & Riau, ID \\
\hline Sago plantation & 762 & -0.24 & 0.15 & 45 & 2.0 & $\mathrm{~N}$ & $\mathrm{~T}$ & Melling et al., 2013 & Sarawak, MY \\
\hline Rubber plantation & 1418 & -0.67 & NA & NA & NA & $\mathrm{Y}$ & I & Husnain et al., 2014 & Riau, ID \\
\hline Rubber plantation & 1408 & -0.69 & 0.23 & 43 & 2.3 & $\mathrm{Y}$ & $\mathrm{T}$ & Wakhid et al., 2017 & Cent. Kalimantan, ID \\
\hline Bare ground & 1718 & -0.70 & 0.12 & 50 & 1.2 & $\mathrm{Y}$ & I & Husnain et al., 2014 & Riau, ID \\
\hline Mixed forest & 993 & -0.46 & 0.15 & 48 & 1.8 & $\mathrm{~N}$ & $\mathrm{~T}$ & Melling et al., 2013 & Sarawak, MY \\
\hline Burnt \& drained forest & 450 & -0.26 & NA & 58 & NA & $\mathrm{N}$ & $\mathrm{S}$ & Hooijer et al., 2014 & Cent. Kalimantan, ID \\
\hline Burned forest (DB) $\dagger \dagger$ & 382,362 & $-0.18,-0.09$ & NA & NA & NA & $\mathrm{N}$ & $\mathrm{B}$ & Hirano et al., 2014 & Cent. Kalimantan, ID \\
\hline Undrained forest (UF) & $698,745^{*}$ & $-0.23,-0.39 *$ & 0.11 & 50 & 1.9 & $\mathrm{~N}$ & $\mathrm{~T}$ & This study & Cent. Kalimantan, ID \\
\hline Drained forest (DF) & $775,825^{*}$ & $-0.55,-0.59 *$ & 0.14 & 50 & 1.6 & $\mathrm{~N}$ & $\mathrm{~T}$ & This study & Cent. Kalimantan, ID \\
\hline Burned forest (DB) & $646,748 *$ & $-0.22,-0.62 *$ & 0.24 & 54 & 1.3 & $\mathrm{~N}$ & $\mathrm{~T}$ & This study & Cent. Kalimantan, ID \\
\hline
\end{tabular}

$*$ Values are from 2014 and 2015.** Data from the literature and our observations for the surface layer.

*** Y: Applied, N: Not applied, NA, No data

**** I, T, B, and S indicate inter-rows, trenching, burnt, and subsidence measurements, respectively.

$\uparrow$ ID and MY indicate Indonesia and Malaysia, respectively.

$\dagger \dagger$ Values are from 2004-2005 and 2005-2006. Bulk density, C, and N content data are from this study.

NA, not available. 


\subsection{Comparison to previous research}

\subsubsection{Studies in the same research area}

Sundari et al. (2012) showed the relationships between GWL and total SR at UF and

DF using automated chamber data measured in 2004-2005. They estimated the annual

SR in 2005 as 1321 and $1244 \mathrm{~g} \mathrm{C} \mathrm{m}^{-2} \mathrm{y}^{-1}$, respectively, for UF and DF, with GWL data using a linear or quadratic equation. The mean GWLs were -0.09 and $-0.51 \mathrm{~m}$ at UF and DF, respectively. We estimated the annual SR on a daily basis using their equation and determined values of 1662 and $1864 \mathrm{~g} \mathrm{C} \mathrm{m}^{-2} \mathrm{y}^{-1}$ at UF (GWL: -0.23 and $-0.39 \mathrm{~m}$ ) and 1296 and $1306 \mathrm{~g} \mathrm{C} \mathrm{m}^{-2} \mathrm{y}^{-1}$ at DF (GWL: -0.55 and -0.59 m), in 2014 and 2015, respectively. The drier-than-normal conditions in 2014 and 2015 likely resulted in higher SR estimations. We estimated the PD/SR ratio in 2014 and 2015 at $0.40 \pm 0.07$ (mean of three plots $\pm \mathrm{SD}$ ) and $0.39 \pm 0.06$ at UF and $0.59 \pm 0.02$ and $0.61 \pm 0.02$ at DF (prediction using 3-month mean antecedent GWL), in 2014 and 2015, respectively. These ratios were roughly equivalent to (UF) or higher (DF) than those reported by Melling et al. (2013), who determined (SR-RR)/SR values of $0.40,0.38$, and 0.48 for a mixed peat swamp forest, oil palm plantation, and sago plantation, respectively. The estimated PD/SR ratio showed seasonal variation and was higher in the dry season than in the wet season, in both UF (mean for July to November; $0.51 \pm 0.05$ and $0.47 \pm 0.03$ in 2014 and 2015, respectively) and DF (mean for July to November; $0.67 \pm 0.02$ and $0.67 \pm 0.01$ in 2014 and 2015, 
respectively). This seasonality suggests that the extensive dry conditions that occurred in 2014 and 2015 enhanced the contribution of PD to SR.

Hirano et al. (2014) estimated smaller PD values than were found in our results (382 and $362 \mathrm{~g} \mathrm{C} \mathrm{m}^{-2} \mathrm{y}^{-1}$ with minimum GWLs of -0.82 and $-0.55 \mathrm{~m}$ in $2004-2005$ and 2005-2006, respectively) from the same DB site using automated closed-chamber systems. After ten years, PD was much higher (646 and $748 \mathrm{~g} \mathrm{C} \mathrm{m}^{-2} \mathrm{y}^{-1}$ with minimum GWLs of -0.81 and $-1.53 \mathrm{~m}$ in 2014 and 2015, respectively), suggestive of the effects of both longer and stronger dry seasons (2014 and 2015) and a new drainage canal nearby. Applying the PD-prediction equation to data from DB by Hirano et al. (2014) for 2014 and 2015 resulted in PD values of 637 and $1093 \mathrm{~g} \mathrm{C} \mathrm{m}^{-2} \mathrm{y}^{-1}$, almost equivalent to and much greater than our predictions in 2014 and 2015, respectively (Table 4). The differences between the two predictions for 2015 may be attributed to the much higher GWL during their observation period (minimum: $-0.8 \mathrm{~m}$ ) than our observation year in 2015 (minimum: $-1.52 \mathrm{~m}$ ). In other words, they did not include PD data associated with lower GWLs in their equation. In addition, after Hirano et al. (2014) completed their measurements, the site was burned in 2009 , which changed the physical and chemical properties of the surface peat. The predicted PD based on subsidence measurement (Hooijer et al., 2014) in the same region after the fire of $2009\left(450 \mathrm{~g} \mathrm{C} \mathrm{m}^{-2} \mathrm{y}^{-1}\right)$ was also 
comparable with the results of Hirano et al. (2014) and our study.

The PD values at our sites for the same period until the end of November 2015 (UF: $755 \pm 99$, DF: $822 \pm 24$, DB: $747 \pm 37 \mathrm{~g} \mathrm{C} \mathrm{m}^{-2} \mathrm{y}^{-1}$ ) were much lower than the annual PD at a rubber plantation site (1408 $\mathrm{g} \mathrm{C} \mathrm{m}^{-2} \mathrm{y}^{-1}$ in December 2014 to December 2015; Wakhid et al., 2017). This can probably be attributed to the lower GWL due to drainage and the higher bulk density of the peat after compaction at the rubber plantation (Table 4). Moreover, fertilizer application at plantations could also explain this difference (Jauhianinen et al., 2014; Comeau et al., 2016) due to improvements in peat nutrient conditions, which would support microbial activity.

\subsubsection{Research on heterotrophic respiration}

Table 4 shows a comparison of the annual PD (or SR-RR) in tropical peat reported in the literature for several types of plantations, forests, and a burned site. The PD values at our sites were lower than those of most plantation sites in Indonesia (oil palm: 930-1042 g C $\mathrm{m}^{-2} \mathrm{y}^{-1}$ [Dariah et al., 2014], $1800 \mathrm{~g} \mathrm{C} \mathrm{m}^{-2} \mathrm{y}^{-1}$ [Husnain et al., 2014]; acacia: $2182 \mathrm{~g} \mathrm{C} \mathrm{m}^{-}$ ${ }^{2} \mathrm{y}^{-1}$ [Jauhianinen et al., 2012]; and rubber: $1418 \mathrm{~g} \mathrm{C} \mathrm{m}^{-2} \mathrm{y}^{-1}$ [Husnain et al., 2014] and $1408 \mathrm{~g} \mathrm{C} \mathrm{m}^{-2} \mathrm{y}^{-1}$ [Wakhid et al., 2017]) and comparable to the results from Sarawak, Malaysia $\left(693,762\right.$, and $993 \mathrm{~g} \mathrm{C} \mathrm{m}^{-2} \mathrm{y}^{-1}$ at oil palm, sago, and mixed forest sites, respectively [Melling et al., 2013]). The greater PD at Indonesian plantations was partly 
due to the lower GWL there than at the other plantation sites (Table 4), where GWLs are usually lower due to drainage canals. The significantly larger PD values at DB after the canal excavation than before the excavation suggested that the decrease in GWL from waterlogged conditions enhanced PD in the burned area. Moreover, this suggests that increasing the number of drainage canals enhances $\mathrm{CO}_{2}$ efflux in areas of burned peat. Stable PD ranges are expected at plantations that maintain GWLs in the drained condition $(\leq-0.6 \mathrm{~m})$. By contrast, larger variation in PD are expected at non-plantation sites without water management (i.e., larger GWL variation), such as our observation sites. The PD values at an acacia plantation and several oil palm plantations were more than double our results, which can partially be attributed to the lower $\mathrm{C} / \mathrm{N}$ ratio at the acacia plantation with its richer organic matter (Hergoualc'h and Verchot, 2011) or the positive effect of fertilizer on $\mathrm{CO}_{2}$ emissions, particularly in agricultural peatland (Jauhiainen et al., 2014). In addition, Könönen et al. (2016) analyzed peat in the same area in Central Kalimantan and reported that the distribution of peat carbon compounds, which is related to labile and recalcitrant compounds, can be altered as a result of both drainage and fires. This underlines the importance of measuring both the physical conditions and peat chemical condition (nutrients, carbon compounds, etc.) in PD studies. 


\section{Conclusions}

We measured soil $\mathrm{CO}_{2}$ efflux due to oxidative PD in trenching plots using the closed-chamber method at three sites representing different types of land use (UF, DF, and DB) on tropical peat in Central Kalimantan, Indonesia. PD exhibited seasonality, and was lower in the wet (high-GWL) season and higher in the dry (low-GWL) season. The mean PD values among the three daily measurements during the observation dates over the 2 years of the study did not differ significantly at the three study sites. PD showed a quadratic convex upward relationship with GWL at UF and DF. At DF, the 3-month mean GWL explained PD better than did the daily GWL. At DB, the relationship between PD and GWL differed between the dry and wet seasons. The difference in these relationships was probably due to changes in the physical characteristics of peat and hydrological conditions due to drainage and peat fires. PD was estimated from GWL data at all sites. The annual PD was estimated for the 2 observation years (2014 and 2015), which experienced drier-than-normal conditions. At DF, where the GWL remained below the peat surface throughout the observation period, there were no differences in annual PD between the 2 years. The more variable GWL conditions at UF and DB resulted in yearly differences in PD, and much greater PD values were observed at both sites under the severely dry conditions in 2015, a strong El Niño year. The annual PD values at our sites were much lower than those reported at plantations (e.g., oil palm, rubber, and acacia) in 
previous reports on tropical peatland, although our sampling period (2014-2015) had the driest conditions among the 10 years during which these studies took place. Besides the changes in GWL due to changes in land use, both bulk density, which can affect both water permeability and oxygen supply to the deeper zone, and litter and fertilizer input, which can affect nutrient conditions, were important determining factors for PD. This underlines the importance of measuring both the physical and chemical characteristics of peat in PD studies. Finally, the prediction of the seasonal variation in PD suggested that the increased dryness of the seasons stemming from climate change and the expansion of plantations in peat areas could enhance PD in both pre- and post-burned tropical peatlands.

\section{Acknowledgments}

We thank anonymous reviewers for their valuable comments on an earlier draft of this manuscript. This work was supported by the Ministry of Education, Culture, Sports, Science and Technology for Science Research (JSPS KAKENHI; grant numbers 25257401 and 15H05625), the Environment Research and Technology Development Fund (grant numbers 2-1504 and 4-1504) by the Ministry of the Environment, Japan, the Asahi Glass Foundation, Grant for Environmental Research Projects from The Sumitomo Foundation, and the Research Institute for Humanity and Nature, Japan. We thank Dr. Hiroyuki Yamada for his advice on groundwater level measurements.

\section{References}

Aguilos, M., Takagi, K., Liang, N.,Watanabe, Y., Teramoto,M., Goto, S., Takahashi, Y.,Mukai, H., Sasa, K., 2013. Sustained large stimulation of soil heterotrophic respiration rate and its temperature sensitivity by soil warming in a cool-temperate $\begin{array}{lllll}\text { forested } & \text { peatland. } & \text { Tellus }\end{array}$ http://dx.doi.org/10.3402/tellusb.v65i0.20792. 
Ali, M., Taylor, D., Inubushi, K., 2006. Effects of environmental variations on $\mathrm{CO}_{2}$ efflux from a tropical peatland in eastern Sumatra. Wetlands 26, 612-618.

Birch, H. F., 1958. The effect of soil drying on humus decomposition and nitrogen availability. Plant Soil, 10, 9-31.

Christian, T. J., Kleiss, B., Yokelson, R. J., Holzinger, R., Crutzen, P. J., Hao, W. M., Saharjo, B. H., Ward, D. E., 2003. Comprehensive laboratory measurements of biomass-burning emissions: 1. Emissions from Indonesian, African, and other fuels. J. Geophys. Res: Atm. 108. D23, 4719.

Comeau, L. - P., Hergoualc'h, K., Hartill, J., Smith, J., Verchot, L. V., Peak, D., Salim, A. M., 2016. How do the heterotrophic and the total soil respiration of an oil palm plantation on peat respond to nitrogen fertilizer application? Geoderma 268, 4151.

Couwenberg, J., Dommain, R., Joosten, H., 2010. Greenhouse gas fluxes from tropical peatlands in South-east Asia. Glob. Chang. Biol. 16:1715-1732. http://dx.doi.org/10.1111/j.1365-2486.2009.02016.x.

Couwenberg, J., Thiele, A., Tanneberger, F., Augustin, J., Bärisch, S., Dubovik, D., Liashchynskaya、 N., Michaelis, D., Minke, M., Skuratovich, A., Joosten, H., 2011. Assessing greenhouse gas emissions from peatlands using vegetation as a proxy. Hydrobiologia, 674, 67-89.

Couwenberg, J., Hooijer, A., 2013. Towards robust subsidence-based soil carbon emission factors for peat soils in South-east Asia, with special reference to oil palm plantations. Mires and Peat 12, 1-13.

Dariah, A., Marwanto, S., Agus, F., 2014. Root- and peat-based $\mathrm{CO}_{2}$ emissions from oil palm plantations. Mitig. Adapt. Strateg. Glob. Chang. 19, 831-843. http://dx.doi.org/10.1007/s11027-013-9515-6.

Dommain, R., Couwenberg, J., Glaser, P.H., Joosten, H., Suryadiputra, I.N.N., 2014. Carbon storage and release in Indonesian peatlands since the last deglaciation. Quat. Sci. Rev. 97, 1-32. http://dx.doi.org/10.1016/j.quascirev.2014.05.002.

Hergoualc'h, K., Verchot, L.V., 2011. Stocks and fluxes of carbon associated with land use change in Southeast Asian tropical peatlands: a review. Glob. Biogeochem. Cycles 25, GB2001. http://dx.doi.org/10.1029/2009GB003718.

Hirano, T., Jauhiainen, J., Inoue, T., Takahashi, H., 2009. Controls on the carbon balance of tropical peatlands. Ecosystems 12:873-887. http://dx.doi.org/10.1007/s10021008-9209-1.

Hirano, T., Segah, H., Kusin, K., Limin, S., Takahashi, H., Osaki, M., 2012. Effects of disturbances on the carbon balance of tropical peat swamp forests. Global Change 
Biol. 18, 3410-3422.

Hirano, T., Kusin, K., Limin, S., Osaki, M., 2014. Carbon dioxide emissions through oxidative peat decomposition on a burnt tropical peatland. Glob. Chang. Biol. 20, 555-565. http://dx.doi.org/10.1111/gcb.12296.

Hooijer, A., Page, S., Canadell, J.G., Silvius, M., Kwadijk, J., Wösten, H., Jauhiainen, J., 2010. Current and future $\mathrm{CO}_{2}$ emissions from drained peatlands in Southeast Asia. Biogeosciences 7. 1505-1514. http://dx.doi.org/10.5194/bg-7-1505-2010.

Hooijer, A., Page, S., Jauhiainen, J., Lee,W.A., Lu, X.X., Idris, A., Anshari, G., 2012. Subsidence and carbon loss in drained tropical peatlands. Biogeosciences 9, 1053-1071. http://dx.doi.org/10.5194/bg-9-1053-2012.

Hooijer, A., Page, S., Navratil, P., Vernimmen, R., Van der Vat, M., Tansey, K., Konecny, K., Siegert, F., Ballhorn, U., Mawdsley, N., 2014. Carbon Emissions From Drained and Degraded Peatland in Indonesia and Emission Factors for Measurement, Reporting and Verification (MRV) of Peatland Greenhouse Gas Emissions - A Summary of KFCP Research Results for Practitioners. IAFCP, Jakarta, Indonesia.

Husnain, H.,Wigena, I.G.P., Dariah, A.,Marwanto, S., Setyanto, P., Agus, F., 2014. CO 2 emissions from tropical drained peat in Sumatra, Indonesia. Mitig. Adapt. Strateg. Glob. Chang. 19, 845-862. http://dx.doi.org/10.1007/s11027-014-9550-y.

Ishikura, K., Yamada, H., Toma, Y., Takakai, Morishita, T., Darung, U., Limin, A., Limin, S. H., Hatano, R., 2017. Effect of groundwater level fluctuation on soil respiration rate of tropical peatland in Central Kalimantan, Indonesia, Soil Sci. Plant Nut. 63, 1-13. http://dx.doi.org/10.1080/00380768.2016.1244652

IPCC., 2006. IPCC Guidelines for National Greenhouse Gas Inventories. Institute for Global Environmental Strategies (IGES) for the IPCC, Kanagawa, Japan.

IPCC., 2014, Supplement to the 2006 IPCC Guidelines for National Greenhouse Gas Inventories: Wetlands, Hiraishi, T., Krug, T., Tanabe, K., Srivastava, N., Baasansuren, J., Fukuda, M. and Troxler, T.G. (eds). Published: IPCC, Switzerland.

Jauhiainen, J., Hooijer, A., Page, S.E., 2012. Carbon dioxide emissions from an Acacia plantation on peatland in Sumatra, Indonesia. Biogeosciences 9, 617-630. http://dx.doi.org/10.5194/bg-9-617-2012.

Jauhiainen, J., Kerojoki, O., Silvennoinen, H., Limin, S., Vasander, H., 2014. Heterotrophic respiration in drained tropical peat is greatly affected by temperature - a passive ecosystem cooling experiment. Environ. Res. Lett. 9, 105013. http://dx.doi.org/10.1088/1748-9326/9/10/105013. 
Könönen, M., Jauhiainen, J., Laiho, R., Kusin, K., Vasander, H., 2015. Physical and chemical properties of tropical peat under stabilised land uses. Mires and Peat 16, $1-13$.

Könönen, M., Jauhiainen, J., Laiho, R., Spetz, P., Kusin, K., Limin, S., Vasander, H. 2016 Land use increases the recalcitrance of tropical peat. Wetlands Ecol. Managem. 24, 717-731.

Krisnawati, H., Adinugroho, W.C., Imanuddin, R., Hutabarat, S., 2015. Estimation of Annual Greenhouse Gas Emissions from Forest and Peat Lands in Central Kalimantan. Research and Development Center for Conservation and Rehabilitation, Forestry Research and Development Agency, Bogor, Indonesia.

Kwon, M. J., Haraguchi, A., Kang, H., 2013. Long-term water regime differentiates changes in decomposition and microbial properties in tropical peat soils exposed to the short-term drought, Soil Biol. Biochem. 60, 33-44.

Lampela M, Jauhiainen J, Vasander H. Surface peat structure and chemistry in a tropical peat swamp forest. Plant and Soil 2014; 382: 329-347.

Langner, A., Siegert, F., 2009. Spatiotemporal fire occurrence in Borneo over a period of 10 years. Glob. Change Biol. 15, 48-62.

Marumoto, T., Kai, H., Yoshida, T., Harada, T., 1977. Drying effect on mineralizations of microbial cells and their cell walls in soil and contribution of microbial cell walls as a source of decomposable soil organic matter due to drying. Soil Sci. Plant Nutr. 23, 9-19.

Malhi, Y., Wright, J., 2004. Spatial patterns and recent trends in the climate of tropical rainforest regions. Phil. Trans. Royal Soc. London. B. 359, 331-329.

Melling, L., Hatano, R., Goh, K.J., 2005. Soil $\mathrm{CO}_{2}$ flux from three ecosystems in tropical peatland of Sarawak, Malaysia. Tellus 57B, 1-11.

Melling, L., Yun Tan, C.S., Goh, K.J., Hatano, R., 2013. Soil microbial and root respirations from three ecosystems in tropical peatland of Sarawak, Malaysia. J. Oil Palm Res. 25, 44-57.

Miettinen, J., Liew, S. C., 2010. Degradation and development of peatlands in Peninsular Malaysia and in the islands of Sumatra and Borneo since 1990. Land Degrad. Develop. 21, 285-296.

Miettinen, J., Shi, C., Liew, S. C., 2012. Two decades of destruction in Southeast Asia's peat swamp forests. Front. Ecol. Environ. 10, 124-128.

Miettinen, J., Shi, C., Liew, S. C., 2016. Land cover distribution in the peatlands of Peninsular Malaysia, Sumatra and Borneo in 2015 with changes since 1990. Global Ecol. Conserv. 6, 67-78. 
Page, S.E.,Wust, R.A.J.,Weiss, D., Rieley, J.O., Shotyk,W., Limin, S.H., 2004. A record of late pleistocene and holocene carbon accumulation and climate change from an equatorial peat bog (Kalimantan, Indonesia): implications for past, present and future carbon dynamics. J. Quat. Sci. 19, 625-635. http://dx.doi.org/10.1002/jqs.884.

Page, S., Hosciło, A., Wösten, H., Jauhiainen, J., Silvius, M., Rieley, J., Ritzema, H., Tansey, K., Graham, L., Vasander, H., Limin, S., 2009. Restoration ecology of lowland tropical peatlands in Southeast Asia: current knowledge and future research directions. Ecosystems 12, 888-905.

Page, S.E., Rieley, J.O., Banks, C.J., 2011. Global and regional importance of the tropical peatland carbon pool. Glob. Chang. Biol. 17, 798-818. http://dx.doi.org/10.1111/j.1365-2486.2010.02279.x.

Sano, T., Hirano, T., Liang, N., Hirata, R., Fujinuma, Y., 2010. Carbon dioxide exchange of a larch forest after a typhoon disturbance. For. Ecol. Managem. 260, 22142223.

Schiermeier, Q., 2015. Hunting the Godzilla El Niño. Nature 526, 490-491.

Snyder, C. S., Bruulsema, T. W., Jensen, T. L., Fixen, P. E., 2009. Review of greenhouse gas emissions from crop production systems and fertilizer management effects. $\begin{array}{llll}\text { Agri. Ecosys. } & \text { Environ. }\end{array}$ http://dx.doi.org/10.1016/j.agee.2009.04.021.

Sorensen, K. W., 1993. Indonesian peat swamp Forests and their role as a carbon sink. Chemosphere 27, 1065-1082.

Sulzman, E. W., Brant, J. B., Bowden, R. D., Lajtha, K., 2005. Contribution of aboveground litter, belowground litter, and rhizosphere respiration to total soil $\mathrm{CO}_{2}$ efflux in an old growth coniferous forest. Biogeochemistry 73, 231-256.

Sundari, S., Hirano, T., Yamada, H., Kusin, K., Limin, S., 2012. Effects of groundwater level on soil respiration in tropical peat swamp forests. J. Agric. Meteorol. 68, 121-134.

Yulianti, N., H. Hayasaka, Usup, A., 2012. Recent forest and peat fire trends in Indonesia: The latest decade by MODIS hotspot data. Glob. Environ. Res. 16, 105-116.

van Gestel, M., Merckx, R., Vlassak, K., 1993. Microbial biomass responses to soil drying and rewetting: The fate of fast- and slow-growing microorganisms in soils from different climates, Soil Biol. Biochem. 25, 109-123.

Wakhid, N., Hirano, T., Okimoto, Y., Nurzakiah, S., Nursyamsi, D., 2017. Soil carbon dioxide emissions from a rubber plantation on tropical peat, Sci. Tot. Environ. 581-582, 857-865. http://dx.doi.org/10.1016/j.scitotenv.2017.01.035 